\title{
Punctuation as Rhetorical Notation? From Colon to Semicolon
}

\author{
Neil Rhodes
}

\begin{abstract}
A BSTRACT The word punctuation is not used in English until 1593. The earlier term, used from the late Middle Ages, was pointing, which meant a sign system for pausing in reading. This rhetorically based principle of punctuation continued to operate during the sixteenth century but was gradually superseded by the logical system, which mapped out the grammatical structure of a sentence. The punctuation mark that best typifies the earlier system is the colon, since this was used to identify the cola (members) of a periodic discourse and represented a mid-length pause. This essay will discuss different uses of the colon in a range of printed texts from the second half of the sixteenth century (psalms, hexameter verse, translations from Cicero, prose pamphlets, and drama). Neil Rhodes argues that the 1590 s is the decade when the semicolon supersedes the colon in a move that encapsulates the broader transition from pointing to punctuation. In "Voicing Text 1500-1700," ed. Jennifer Richards and Richard Wistreich, special issue, http://muse.jhu.edu/ muse.jhu.edu/resolve/66. KE Y WOR DS: sixteenth-century shifts in punctuation; Thomas Nashe; Ben Jonson; rhetorical versus syntactical notation
\end{abstract}

\begin{abstract}
ONE OF THE DEFINING FEATURES of the early modern period, and also one of the most confusing for the modern cultural historian or literary scholar, is the simultaneous presence of two overlapping but opposing systems of thought. The new was superimposed upon the old in ways that we now find very difficult to grasp. This is most obviously apparent in the continuation of geocentric thinking for decades after the Copernican model of the universe had found its way into popular understanding, and it is apparent, too, in the theory and practice of punctuation. This may at first sight seem an absurd juxtaposition of the vastly significant with the pedantic or trivial, and yet Cicero had made the connection in De oratore, where he relates the order of the universe, with the earth at the center, to the structure of the body and then to "periods and the pointing of words" (clausulas... interpuncta verborum)
\end{abstract}

HUNTINGTON LIBRARY QUARTERLY | VOL. 82, NO. 1

Pp. 87-105. ( 2019 by Henry E. Huntington Library and Art Gallery. ISSN 0018-7895 | E-ISSN 1544-399x. All rights reserved. For permission to photocopy or reproduce article content, consult the University of Pennsylvania Press Rights and Permissions website, http://www.upenn.edu/pennpress/about/permissions.html. 
and "the invention of stops," which create pleasing harmony. ${ }^{1}$ As well as suggesting its microcosmic significance, discussions of punctuation in writing about style and composition in antiquity give it an important role in the relationship between speech and the body, between language and music, and between the sounded and the written word. This persists in the sixteenth century. And insofar as the two systems of punctuation operating in the early modern period contrast the physiological and rhetorical with the abstract and logical, they also bear witness to a body-mind transition that is intrinsic to the Cartesian revolution. Though punctuation may not have had its Copernicus, its evolution in the early modern period speaks volumes.

The two systems of punctuation we are talking about are the one that marks pauses for breath and acts as a guide to speaking or reading aloud, and the one that is principally concerned with expressing the syntactical relationship between the different parts of a sentence. For the origins of the first system we can look to Aristotle, who contrasts the "extended style ... which has no stop within itself" with "the contracted style," which "is that in periods." The extended style is unpleasant because speakers grow breathless, just as "runners approaching the turning point pant and grow faint." The contracted or periodic style, on the other hand, has "an easily surveyed magnitude" and is also "easily memorized ... because the periodic style is numerical and number is the most easily remembered thing of all."2 Punctuation begins as a system for marking pauses for breath between the component parts (clauses as well as sentences) of the "contracted" style. It is also linked to prosody because this kind of style is based on "number," and this in turn implies a relationship with music. 3

The three basic punctuation marks operating in the early modern periodcomma, colon, and period-actually take their names from the units of discourse themselves rather than from the pauses between them or the signs that represent these. They are Greek in origin and are carried over into Latin, though Latin has its own terminology for the pauses. The pseudo-Ciceronian Rhetorica ad Herennium explains that "It is called a Comma or Phrase when single words are set apart by

1. De oratore, trans. E. W. Sutton and H. Rackham (Cambridge, Mass., 1948), 3.45-46 (178-81). Cicero nevertheless seems to have disdained the use of punctuation marks (librariorum notae) in his own compositions; see Shane Butler, "Cicero's Capita," in The Roman Paratext: Frame, Text, Readers, ed. Laura Jansen (Cambridge, 2014), 97-98. (Butler does, however, consider the possibility that Cicero was responsible for the capitulation of his texts.)

2. Aristotle, The Art of Rhetoric, trans. H. C. Lawson-Tancred (London, 2004), 232 (III.9 1409b).

3. In one of the earliest post-Aristotelian treatises on style, Demetrius begins by analogizing prose clauses and poetic meter; see Demetrius, On Style, ed. and trans. Doreen C. Innes (Cambridge, Mass., 1999), 345. However, in his discussion of the period, he turns Aristotle's own analogy with breathless runners into a positive stylistic feature, explaining that the word "implies that it ... is speeding towards a definite goal, like runners sprinting towards the starting place"; see Janel Mueller, "Periodos: Squaring the Circle," in Renaissance Figures of Speech, ed. Sylvia Adamson, Gavin Alexander, and Katrin Ettenhuber (Cambridge, 2007), 62. 
pauses in staccato speech" and that "Colon or clause is the name given to a sentence member, brief and complete, which does not express the entire thought, but is in turn supplemented by another colon." 4 A period is a unit of discourse that is complete in itself-that is, a sentence. This is echoed by Quintilian, who supplements his definition with the prosodic qualities noted by Aristotle. There are two main principles of composition, "one relating to the feet, the other to the structures which are produced out of these." Dealing with the latter first, he explains that the comma (incisum) "is a complete thought without completeness of rhythm," while the colon "is a thought which is rhythmically complete, but separated from its parent body and ineffective on its own." 5 So the commata and cola are truncated parts of the body, and the association of punctuation with both the physiological and the aural (rhythm, prosody, music) is fundamental. The editor of Rhetorica ad Herennium writes of kōlon: " $\kappa \omega \lambda \mathrm{ov}$. The concept originated in comparison with the human body; it came into rhetoric from the art of music." ${ }^{6}$ Read in isolation, this note is cryptic; but when seen in the context of discussions of punctuation from Aristotle to Quintilian, it makes sense. This understanding of punctuation as a rhetorical sign system, or system of notation, associated with both music and the body continues into the sixteenth century and beyond. What I aim to do in this essay, then, is to trace the evolution of punctuation from the older system of rhetorical notation to the modern syntactical system and to present the 1590 as as the decade of transition. I shall focus here on the gradual replacement of the colon by the semicolon, taking the work of Thomas Nashe as a test case.

\section{$\sim$ Punctuations: Systems and Terminology}

The term punctuation is not used in English in its modern sense until 1593, when the Oxford English Dictionary gives John Eliot's French-English language manual Orthoepia Gallica as its first citation.7 In a Rabelaisian address to teachers of French in London he urges them "to peruse my periodicall punctuations, find fault with my pricks, nicks, and tricks," using the term to indicate the marks or signs themselves rather than the system of which they are a part. ${ }^{8}$ This was referred to from the late Middle Ages as pointing and sometimes in its Latin form as punctuacio. What pointing meant was

4. [Pseudo-Cicero], Ad C. Herennum de ratione dicendi (Rhetorica ad Herennium), trans. Harry Caplan (Cambridge, Mass., 1914), 294-95 (4.19.26).

5. Quintilian, The Orator's Education [Intitutio oratoria], ed. and trans. Donald A. Russell, 5 vols. (Cambridge, Mass., 2001), 4:228-29 (9.4.121-23).

6. Rhetorica ad Herennium, trans. Caplan, 294n 45.

7. Vivian Salmon claims 1539 as the date of its first appearance but gives no reference; see “English Punctuation Theory 1500-180o," Anglia 106 (1988):307-8.

8. John Eliot, Ortho-epia Gallica (London, 1593), sig. A4r (Oxford English Diction$\operatorname{ary}[O E D]$, s.v. "punctuation," sense $2 \mathrm{a}$ ). There is an earlier instance of the word being used to refer to psalm notation (sense 1a,1531). The term prick covers both musical and verbal notation (OED, s.v. "prick, $n$," senses $3 \mathrm{a}-\mathrm{b})$. 
a sign system for pausing in reading. ${ }^{9}$ In the sixteenth century these pauses are sometimes called staies, but more frequently "distinctions." This follows the Latin term distinctiones, which was used to refer to punctuation marks in the Middle Ages and which is preserved in the sixteenth century in Lily's Latin grammar. Here the three basic punctuation marks are covered in the section called "De sententiarum punctis" and are given as "subdistinctio," "media distinctio," and "plena ac perfecta distinctio" along with their Greek (and modern English) equivalents. ${ }^{10}$ The term distinction is also used in sixteenth-century English to refer to punctuation as a system. So John Hart writes in his Orthographie of "distinction or pointing, which (well obserued) maye yeelde the matter, much the readier to the senses, as well to the eie as to the eare"; and Richard Mulcaster calls one of the chapters in his Elementarie "Of Distinction," explaining this as a system that helps with "the right and tunable vttering of our words and sentences." 11 Mulcaster says that although people have written whole treatises on punctuation, as a teacher he wants to ensure "the right framing of the tender childes mouth," so he is only concerned with that "which tendeth to the qualifying of our voice." 12 Mulcaster, then, would certainly appear to see punctuation principally as a system of rhetorical notation, closely associated with both music ("tunable") and the body. These associations are made even more explicitly by John Hart, though with reference to different punctuation marks. He writes that the Greek term comma is called incisum in Latin "and is in reading the shortest rest, neare the time of a Crachet in musike.” But he gives no musical equivalent for the colon, reporting instead that it is called in Latin

artus membrorum or internodium, which is the space, or the bone, fleshe and skinne betwixt two ioyntes, and so (accompting a full sentence, as a complete bodie) these two prickes may well signifie a great part therof, : as of the body, may be taken from the ancle ioint to the knee, and from the knee to the huckle or buttock ioynt. ${ }^{13}$

It is difficult to know what to make of the fact that Hart, or his printer, has decided to use both punctuation marks after "therof," which makes a nonsense of their function as signals of different pause lengths, since they cannot both be observed simultaneously. But what is clear is that where Mulcaster sees the physical aspect of punctuation in practical terms as a form of voice training, for Hart the musical and the physiological represent two alternative sources of metaphor for the sign system as a whole.

9. See OED, s.v. "pointing, n.1," sense 4a: "Promptorium Parvulorum (Harl. 221) 407 Poyntynge, or pawsynge in redyng, punctuacio."

10. William Lily, Institutio compendiaria totius grammaticae (London, 1540), fol. 4r-v.

11. John Hart, An Orthographie (London, 1569), fol. 4or; Richard Mulcaster, The First Part of the Elementarie (London, 1582), 148.

12. Mulcaster, Elementarie, 149.

13. Hart, Orthographie, fol. $40 \mathrm{v}$. 
Both writers refer to punctuation as distinction, but what the Latin artus membrorum also points us to is the term that might best capture the different ways in which Hart and Mulcaster represent punctuation, and also to the two different systems of punctuation that overlapped with each other in the early modern period. This is the term articulation. ${ }^{14}$ The words articulate and articulately do appear in sixteenth-century English, but they are uncommon. The concept represented by articulation, however, perfectly suits the subject because it combines the sense of distinct utterance with that of physiological connection. Articulation paradoxically both divides and connects, which is what punctuation does. Articulation in the sense of clear enunciation renders distinct the aural units of any discourse, but in its other anatomical sense it links together the different sense units to make the single body of a sentence. Seen in this light, the commonest term for punctuation in the early modern period, distinction, may also have been understood to refer to both the ancient and modern concepts of punctuation. Virtus distinguendi (excellence in separating) was the expression used by Quintilian to denote a speaker's ability to decide when and for how long to pause. ${ }^{15}$ But distinction also lends itself to a very different understanding of punctuation as a system for disambiguating the sense of any discourse by marking out or "distinguishing" its syntactical components. The early modern term distinction is transferred from one concept of punctuation to the other, and the modern term articulation helps us to understand how that transition works.

It is possible to trace the gradual evolution of punctuation from one system to the other between the mid-sixteenth and mid-seventeenth centuries. In the draft of his treatise on orthography written in 1551, John Hart says that the function of punctuation is to show us "how to rest and stay." 16 Puttenham, writing in 1589, elaborates on this in his memorable description of the "three manner of pauses," which represent different resting points or "easements" on a journey; but he also notes that the three pauses "be used for a commodious and sensible distinction of clauses in prose," so he is fully aware of the two different functions of punctuation. ${ }^{17}$ By the time we get to Charles Butler in 1633, it is clear that "points" are "for the better understanding of Woords" and that they have, for him at least, "a markedly syntactical function," as

14. On articulation, see my discussion in "Articulate Networks: The Self, the Book, and the World," in The Renaissance Computer: Knowledge Technology in the First Age of Print, ed. Neil Rhodes and Jonathan Sawday (London, 2000), 184-96; and in Shakespeare and the Origins of English (Oxford, 2004), 5-29.

15. See Bruce R. Smith, The Acoustic World of Early Modern England: Attending to the O-Factor (Chicago, 1999), 238.

16. John Hart, "The opening of the unreasonable writing of our Inglish toung," Royal MS ${ }_{17}$ C VII, British Library, quoted in Vivian Salmon, "Orthography and Punctuation," in The Cambridge History of the English Language, vol. 3, 1476-1776, ed. R. Lass (Cambridge, 1999), 22. 17. George Puttenham, The Art of English Poesy: A Critical Edition, ed. Frank Whigham and Wayne A. Rebhorn (Ithaca, N.Y., 2007), 165. 
Walter Ong remarks. ${ }^{18}$ But this is not a consistent development, and Ong also cites the example of Simon Daines, writing in 1640, who says that when teaching his pupils the art of "distinct and ready reading," he would follow his own music teacher's lessons in keeping time, "to inure them to the distinction of their pauses."19 An understanding of punctuation as a system of rhetorical notation clearly continued long after John Hart.

Equally clear is that throughout the period writers thought of punctuation as having different functions in different kinds of text and in different contexts. Puttenham, for example, assigns a more syntactical function to punctuation in prose than in poetry. This is the function assigned to punctuation in many scholarly contexts, including the interpretation of scripture, and it is essential in the case of translation. Mulcaster wrote about punctuation in the context of English, but fellow schoolmaster John Brinsley, writing thirty years later, takes a rather different approach when dealing with Latin. His instructions to schoolboys on how to use punctuation to help them construe the meaning of a passage of Latin are precise. They should read each sentence through "to a Period or full point, and there to stay," and then see how it all fits together. He encourages the pupil to

marke the sentence well, and to obserue all the points in it, both Commaes and Colons; or lesse distinctions, and middle distinctions: that so he may see and consider both the beginning, middest, and end of the sentence together; and also each clause in it. ${ }^{20}$

We could not wish for a clearer statement of the syntactical-semantic function of punctuation as a guide to meaning. But Thomas Heywood, writing in the same year, points out that those same scholars may have to use punctuation in a quite different way when they are employed in any "publicke exercise" at a university. Here they must rely upon rhetoric, which "not onely emboldens a scholer to speake, but instructs him to speake well, and with iudgement, to obserue his comma's, colons, \& full poynts, his parentheses, his breathing spaces, and distinctions." ${ }^{21}$ This is an equally explicit statement about punctuation as an alternative system of rhetorical notation. In this case, though the texts may be similar in demanding that readers pay close attention to punctuation, they are being presented in different contexts. Neither writer explains whether the two systems can actually work together.

18. Charles Butler, The English Grammar, or The Institution of Letters, Syllables, and Words (Oxford, 1633), sig. Hiv; Walter J. Ong, "Historical Backgrounds of Elizabethan and Jacobean Punctuation Theory," PMLA 59, no. 2 (1944): 358. Ong is primarily concerned to demonstrate the persistence of the older theory of punctuation.

19. Simon Daines, Orthoepia Anglicana (London, 1640), 69, 71.

20. John Brinsley, Ludus Literarius: or The Grammar Schoole (London, 1612), 95.

21. Thomas Heywood, An Apology for Actors (London, 1612), sig. C3v. 
The writer we might turn to for help with this point is Ben Jonson, who edited his play texts for the 1616 Folio with markedly heavy punctuation and who wrote on the subject in chapter 9 of his English Grammar, "Of the Distinction of Sentences." Sara van den Berg has written eloquently on Jonson's understanding of punctuation, arguing that it is intrinsic to his texts and that it should be preserved in modern editions. Central to her case is Jonson's use of the physiological metaphor at the beginning of chapter 9: "There resteth one generall Affection of the whole, dispersed thorow every member thereof, as the bloud is thorow the body; and consisteth in the breathing, when we pronounce any Sentence." 22 This leads her to claim that he saw the text as an "organic whole," a body preserving "the presence of its author"; and she goes on to argue that this idea of the text as body enabled Jonson to assimilate both the logical and rhetorical conceptions of punctuation into a single system: "If, in the body of a text, logical punctuation marks its skeletal structure, rhetorical punctuation marks its breath." 23 This is seductive but problematic. Grafting one system onto the other means that, in the case of Jonson, the printed play texts are so densely punctuated that they could not possibly be used as a guide to performance. To do so would make all the characters sound asthmatic. So the effect of combining the two systems is actually to obviate the role of punctuation as rhetorical notation. We know from extant dramatic manuscripts that the scripts provided for actors were lightly punctuated. ${ }^{24}$ What Jonson seems to be doing in his printed drama is to separate the literary text from its performed version.

Jonson based his English Grammar on Ramus, whose Grammatica Latina was published in 1585, followed quickly by an English translation in the same year. ${ }^{25}$ It is from Ramus that he derives his idiosyncratic use of the semicolon, which he treats as a shorter pause than the comma: "A sub-distinction is a meane breathing, when the word serveth indifferently, both to the parts of the Sentence going before, and following after, and is marked thus (; )." 26 Whether or not this is a misunderstanding of Ramus, there is no doubt that a system that uses the semicolon in this way (as well as the comma, colon, and period) is completely unworkable as delivery, that is, as rhetorical notation. And the fact that Jonson is following Ramus means that we also need to revise our understanding of Jonson's physiological analogy. We can see Jonson's punctuation as having an anatomical function, but in a purely metaphorical

22. Ben Jonson, The Workes of Benjamin Jonson: The Second Volume (London, 1641), 83.

23. Sara van den Berg, "Marking his Place: Ben Jonson's Punctuation," Early Modern Literary Studies 1, no. 3 (1995): 3 .

24. See Simon Palfrey and Tiffany Stern, Shakespeare in Parts (Oxford, 2007), 318. On "the profound difference between actor's script and the printed edition," see Roger Chartier, The Author's Hand and the Printer's Mind, trans. Lydia G. Cochrane (Cambridge, 2014), 96.

25. The Latine Grammar of P. Ramus (London, 1585).

26. Ben Jonson, The English Grammar, in Workes, 83. Cf. "A subdistinction is that wherewith is distinguished by a litle or smal stay or pause of the breath, betwene the middle word, which may be attributed doubtfully to the part going before and coming after"; Ramus, Latine Grammar, 138-93. 
sense. Like other seventeenth-century anatomies, it is designed to make visible the construction of sentences on the page. It is far removed from the origins of speech in the body. Whatever Jonson may say about blood and breath, the model for his punctuation theory is that of the thinker who was principally responsible for the transition from the oral to the visual in the early modern reception of discourse. ${ }^{27}$ As far as punctuation is concerned, Ramus's treatment of grammar ultimately pushed it in the direction of the abstract logic of mathematics. ${ }^{28}$

\section{$\sim$ Colons and Pauses, Poetry and Prose}

Jonson's idiosyncratic use of the semicolon reflects the fact that the middle rank of the punctuation hierarchy was already occupied by the colon. This is the punctuation mark designated by Lily as "media distinctio" and by Hart as the "artus membrorum," and it is also the sign that is most characteristic of the older system of "pointing." There are many more colons in a sixteenth-century text than in a text that follows the modern, syntactically based system of punctuation, and they have a quite different function from the modern colon. They represent a middle-length pause, but they also act as a joint between the two halves of a sentence. Hence Mulcaster says that the colon "followeth som full branch, or half the sentence, as Tho the daie be long: yet at the last commeth euensong." 29

The colon is the punctuation mark that best represents an understanding of punctuation as rhetorical notation and, as such, it shows us how this older system could affect literature and, more specifically, literary status. Mulcaster's example is from prose, but it is only a couple of beats away from verse, where the colon frequently represents the caesura, the midline break in classical poetry and in English imitations of quantitative verse. We can see it at work in Richard Stanyhurst's translation of the Aeneid:

Down cooms thee countrey: wheare first thee sturdye Chorœbus

By syr Peneleus was slayne, neere consecrat altar

Of the Godesse Pallas: Ripheus lyke villenye suffred.

A man too pietee, to iustice whoalye relying.

So Gods ordayned thee chaunce. Lo oure coompanye slaughtred

Both Dymas and Hypanis: nor thy deuotion holye

Could salue thee Panthus, nor crowne of blissed Apollo.30

27. See Walter J. Ong, Ramus, Method, and the Decay of Dialogue: From the Art of Discourse to the Art of Reason (Cambridge, Mass., 1958).

28. See Timothy J. Reiss, "From Trivium to Quadrivium: Ramus, Method, and Mathematical Technology," in The Renaissance Computer, ed. Rhodes and Sawday, 45-58.

29. Mulcaster, Elementarie, 148.

30. Virgil, Thee First Foure Bookes of Virgil his Aeneis, trans. Richard Stanyhurst (Leiden, 1582), 33-34. 
Stanyhurst's versification has had few admirers, then or now, but he is clearly trying to vary his caesura here by using each of the three punctuation marks, and he is successful in getting the midline break to coincide with the point of connection between two membra, or limbs, marked by the colon. There are occasional midline colons in Surrey's earlier translation $(1554,1557)$, well known as the first attempt at blank verse in English, but they are less frequent than end-of-line colons. Indeed, the absence of any sustained translation of the caesura into English may be one reason why Surrey's sixteenth-century readers did not, in general, find his version of the Aeneid satisfactory.

For Puttenham, punctuation in verse simply meant the caesura. "On caesura" is the title he gives to the chapter that deals with punctuation and that likens the different pauses to resting places on a journey. He introduces the topic with the observation that " $\mathrm{t}$ ] here is no greater difference betwixt a civil and brutish utterance than clear distinction of voices," giving the caesura an elevating as well as an articulating function. ${ }^{31}$ Puttenham is also very much concerned with the equivalence between verse and social rank, and in the hierarchy of form, the highest rank is shared between epic and divine poetry, the latter represented by the psalms. Here, though, we encounter something of a conundrum, because printed verse translations of the psalms in sixteenth-century England took the very low form of the ballad meter, while quite self-consciously using the resources of punctuation to claim higher status for the enterprise. This is how Elizabeth's first archbishop, Matthew Parker, introduces his version of the psalms:

Accent in place: your voyce as needth, note number, poynte, and time:

Both lyfe and grace: good reading breedth, flat verse it reysth sublime.

Observe the trayne: the ceasure marke, To rest with note in close:

Rythme dogrell playne: as dogges do barke, ye make it els to lose. ${ }^{32}$

Parker's colons here and throughout the work act purely as a form of rhetorical notation. They have no grammatical function, and the silent reader will mentally delete many of them (in the first line, for example) so as not to interrupt the sense.

31. Puttenham, Art of English Poesy, 163; on the rules for the caesura in English, see Gavin Alexander, "Commentary," in William Scott, The Model of Poesy, ed. Alexander (Cambridge, 2013), 208-9, note to p. 63.

32. Matthew Parker, The Whole Psalter Translated into English Metre (London, 1567), sig. B1v. 
What is odd about this is that Parker is marking the caesura in the formal context of "rythme" - that is to say, the tetrameter/trimeter combinations of ballad meterrather than classical hexameters like Stanyhurst's, which is where you would expect to find the caesura and therefore the colon. In the shorter lines of the ballad meter, the midline pause sounds rather crude or mechanical, like the great intake of breath in a primary school carol service. One explanation is that Parker is very conscious of the need to defend putting this very high subject matter in the low form of "rythme" or "common measure," as it was later called. This is why he goes on to cite the Venerable Bede, who had sanctioned accentual-syllabic verse in his De arte metrica as far back as the early seventh century. What he may be doing is importing a feature from the much grander hexameter verse line in the form of caesura in order to give the "psalms in rythme" a rather specious dignity.

The most popular English version of the psalms through to the end of the seventeenth century was of course the collection of Thomas Sternhold and John Hopkins (first edition 1549), which predates Parker and which also takes the low form of ballad meter. But there is another, more elevated prose version, which predates Sternhold and Hopkins: the translation by Miles Coverdale, which appeared in his Bible in 1535, was incorporated into the Great Bible of 1539 with a bit of revision, and then made its way into the Book of Common Prayer. This was the more solemn alternative to Sternhold and Hopkins, which was the text for communal singing, and rather remarkably it was the only biblical text in the Book of Common Prayer not to be replaced by the King James Version in 1662.33 This is how Coverdale renders verses 4 and 5 of Psalm 68:

Oh syng unto God, and syng prayses unto his name: magnifye hym that rydeth upon the heavens, as it were upon a horse: prayse ye him in hys name ye[a] and reioyse before hym.

He is a father of the fatherlesse, and defendeth the cause of wyddowes: even God in his holy habitacion. 34

The rules for Hebrew verse had not been discovered when Coverdale produced this, and he was in any case ignorant of the language, but he seems to have intuited the parallelism that is its basic principle and used the colon to map this out on the page. Its function, at least in Coverdale's English, is to get the reader to pause and inwardly digest what has just been said or chanted: the colon-as-punctuation-mark points back to the colon-as-phrase that precedes it to suggest that it has a distinct quality in its own right - that there are perhaps hidden depths that are not apparent in the words themselves. The use of punctuation as rhetorical notation for pause and reflection is

33. See Hannibal Hamlin, Psalm Culture and Early Modern English Literature (Cambridge, 2004), 31-33.

34. [Miles Coverdale], The Bible in Englyshe (London, 1540), Bb4v. 
one reason why this version of the psalms proved so enduring. ${ }^{5}$ In English it is distinctive to Coverdale and does not really work in the short lines of the Parker psalter.

Coverdale is operating at the border of prose and poetry. When mid-Tudor writers translate Cicero, they are working fully in the medium of prose, and here we can see a different form of punctuation as rhetorical notation at work. The following passage is from Nicolas Grimald's version of Cicero's De officiis, which was printed initially in an English-only version in 1556, and then in parallel with the Latin in the 1558 and subsequent editions (fig. 1):

When these bee chaunged by tyme: chaunged is dutie, that it remaines not alwayes alyke. For ther may chaunce some promes, and couenant: that may be unprofitable to be performed, either to him, to whom it is promised: or els to him, that promised it. For (as it is in the fables) if Neptunus hadde not done, that to Theseus he promised: Theseus had not bene berefte of his sonne Hippolitus. ${ }^{36}$

This is an example of the way in which punctuation-mark commas and colons demarcate the commata and cola, in the sense of phrases and clauses. As with the earlier examples, their function is rhetorical, not grammatical, but in a different way from Parker's or Coverdale's psalms. Grimald is using punctuation marks to show how faithful a translator he is. He wants to show how his English follows the pattern of verbal units in the Latin-the commata and cola that structure Cicero's discourse; in fact, he is as it were hyper-faithful, doubling the number of colons in the original Latin (see fig. 1). What Grimald's Cicero also demonstrates is that prose too has its literary effects and that these are characteristically oral, as he interpolates punctuation to mark out the pattern of lengths of phrases. In terms of literary status Cicero is the prose equivalent of Virgil or the psalms and, as in the case of the caesura, Grimald is anxious to measure up, as it were, to the quality of the original. In both secular and sacred contexts, then, and in both poetry and prose, the sixteenth-century colon has the function of binding together the literary and the oral, either by producing antiphonal effects or by modulating the multiple members of a period. By the end of the century, however, all this would start to change.

35. On silence as punctuation, see Cally Hammond, The Sound of the Liturgy: How Words Work in Worship (London, 2015), 143-45. The colon as midline caesura also has a role in the chanting formulae for the psalms. Here "pointing" (as it is still called in Anglican choral psalm-singing) is a system for allocating syllables of text in unequally divided lines to the notes of a regular repeating musical formula; pointing thus has a musical as well as a textual role. (I thank Richard Wistreich for this point.)

36. Marcus Tullius Ciceroes Thre Bokes of Duties, trans. Nicholas Grimald (London, 1558), fols. 13v-14r. The source of Grimald's Latin text cannot be determined, but it is probably one that derives from Erasmus's edition of 1520; see Marcus Tullius Ciceroes Thre Bokes of Duties, ed. Gerald O'Gorman (Washington, D.C., 1980), 16-17. 


\section{de officiis,}

ac de nobis iudicam'. 2 uo then of our felueg. Ehet circabenepracipiut, qui de - fore thcp teache well, that tasit quicquam agere, quod tozblove to bo asuge thphg, dubites equil it, an iniquth. be tight or wozong. fortis A cquitas cnim lucet $1 p \int a p$ berp right fhencth of tt fell fe:dubitatio astếcogitatio - but boubitug Declares semfignificat iniuria. Sed 1ibut often thete befal fer

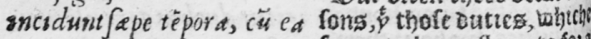
qua maxime videntur dig - feeme to be moft mete fol: nacfe iufto bomix, es iuft nan, andhim, wobom wi que virum bonu dicimus, and becone contratrous: to cormutantwr, fiunta contra - that fonictums it ts iuft no comutantar, filuitq, contra- toteftoze. that is lavde to gia:ve non redderc depofitu, to teftoze. that tslapde to alfo, not to per stram ne fursofo promiffum fournie pzomes bith a mal facere, queq pertinet adve- manne: and to denve tholl ritate et ad fldè, ea negare thingcs, whiche concertil interdum, é non ferstare fit fror it is meete, they bet infit. Referricaim dect ad ferres to thofe founbactort

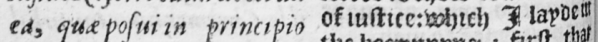
fundameta iuftitic: primu, the begenneng : firft, thal ot ne cui nocedts: deinde vt common pofitte be feruel. commini xtilitati ferratatur. Wohen thefe bee chaungè Eacum tepore comntantur, bp tpme: chaunges is of commetatur officits : vt non wapes alvtre. ffor thet fêper fit $v d \bar{c}$. Foteft enim acci map chatunce fome pzomet dere promiffu al iquod, et co- ano coutenant : that map wetu, ot idefficifit znutule,

\section{Liber.I:}

Fo.14?

mes, either to him, to wohom vel eicui promiffum f $t$, vel tispromfeo: or els to hims, ciqui promiferit. Nam $\sqrt{8}$ is the fables) if feeptu= ( $v t$ in fabulis est) Nepnus hadoe not Done, that to tunus quod Thefeo promiWhefeus he promifed: The ferat, non fecifiet : The feus his fone not bene berefte of filis Hyppolito non effect ore

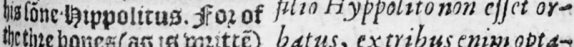
that was the thitoe, wobich) tis (vt (cributar) boc evat whits furp be afteed, for the tertium, quod de Hyppolidath of bippolitus: at we e ti interitw iratus optauit : toheaup waplingex. exther $=$ gwo impetrato in maximos foenenther tijofe promifes luctus incidit. Nec pro-

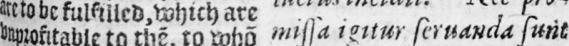

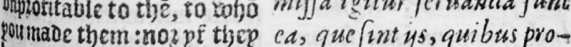
butte you moze, then they mifcris, inutulia: nee fiplus profit bian, whom zou pzo= tibi noceant, quitmilli proIt is againfte dutie, the font, cun promiferis. Congreater barme to be tather tra offrciu c ft, mai damin

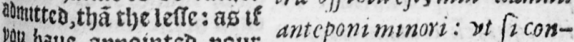
You haue appointeo yout anteponi minori: vi ficonFalle with anpman, to come, fit tueris te cuipian adwoashis confifeller in hts mat $=$ catum in $\mathrm{rem}$ prefcritem

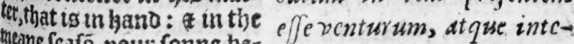
meane feafō, pour fonne be= rim gratuiter agrotare fi-

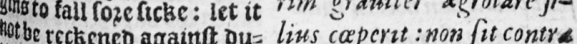
tie,not to perfourme that pe officium, non facere quod

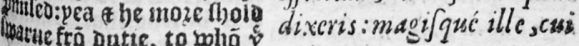
pzomis

FIGURE 1. Marcus Tullius Ciceroes Thre Bokes of Duties, trans. Nicholas Grimald (London, 1558), fol. 14. Courtesy of the University of St. Andrews Library, TypBL.B58TC.

\section{Semicolons, Nashe, and the Advent of Syntactical Punctuation}

If the colon is the most characteristic feature of the older system of pointing, its replacement by the semicolon as the typical midsentence pause might be seen as the most visible feature of the transition from the older, rhetorical system to the modern, logical or syntactical-semantic system of punctuation. The semicolon was introduced into print by Aldus in Venice in the 1490 s and first appears in an English text in Richard Grafton's printing of the Coverdale Bible in 1538 at a press in Paris. It does not appear in a text from an English-based press until later in the century and starts gradually to make its mark from about 1580.37 The term "semi-colon" is first used in

37. See Malcolm Parkes, Pause and Effect: An Introduction to a History of Punctuation in the West (Aldershot, U.K., 1992), 86; Alexander Hume, Of the Orthographie and Congruitie of the Britan Tongue, ed. Henry B. Wheatley, Early English Text Society 5 (London, 1965), 37; A. C. Partridge, Orthography in Shakespeare: A Study of Colloquial Contractions, Elision, Prosody and Punctuation (London, 1964), 124; and Paul Bruthiaux, "The Rise and Fall of the Semi-Colon: English Punctuation Theory and English Teaching Practice," Applied Linguistics 16, no. 1 (1995): $1-14$. 
1589 in a work by Edmund Bunny, where it is used specifically to illustrate how altering the punctuation may alter the sense of a passage. Bunny accuses "R. P." (the Jesuit Robert Parsons) of

altering my woords, and chaunging the pointing or distinguishing of them to make them square better to your purpose... Which, although you doo but with a semi-colon ... yet by better consideration of your maner of pointing in diuers places (vnlesse the printer hath failed therein) it seemeth that you meant to put the whole power of a colon or midle distinction. ${ }^{38}$

The first appearance of the semicolon by name, then, links it explicitly to a syntacticalsemantic concept of punctuation. The name took a long time to become established and Daines still refers to it as the "comma-colon" in 1640, but the sign itself is used with increasing frequency in the last two decades of the sixteenth century. 39 One early enthusiast for the semicolon was John Florio, who may have been attracted by its Italian provenance or simply by the fact that it looked fancy. 40

In many late sixteenth-century texts the colon and semicolon seem to be used interchangeably, yet the modern reader, who is trained to understand punctuation as a logical system of textual demarcation, is liable to see it as having a distinctive function when it appears in these texts. In his authoritative survey of the evolution of punctuation, Malcolm Parkes uses an example from Nashe's Pierce Penilesse (1592) to illustrate the difference between the text as originally punctuated and that of a modern edition, which substitutes the colons of the original with semicolons. The first, as Parkes points out, delineates the rhetorical structure of the period, while the second produces a logical analysis of the text by dividing the period into three sentences. ${ }^{41} \mathrm{It}$ is not difficult to find other examples where the distinctions are made within a single sentence, as here:

but as touching these three, for the first, that is to say negligent sloth, he is to be warned: for the second, he is to be instructed: for the thirde, he is to be helped.

In the modernized text this becomes

38. Edmund Bunny, A Briefe Answer, vnto those idle and frivolous quarrels of R. $P$. against the late edition of the Resolution (London, 1589), 29-30. (This predates the first citation in the OED, which is Jonson's English Grammar, dated 1637.)

39. Daines, Orthoepia Anglicana, 70.

40. See John Florio, Florio's Second Frutes (London, 1591), esp. sig. A4r.

41. See Parkes, Pause and Effect, 87-88. 
But as touching these three: for the first, that is to say negligent sloth, he is to be warned; for the second, he is to be instructed; for the third, he is to be helped. 42

Nashe is a good writer for Parkes to choose to illustrate this point, since his work is generally held to be intensely rhetorical both in the conventional sense and in its self-conscious orality, and it seems worthwhile to develop it by comparing the use of colons with semicolons within the original texts themselves. The results appear in table 1.

There are various inferences that we can draw from this table. The first and most obvious one is that the printer of An Almond for a Parrat may not have had a semicolon in his font and that Charlewood had very few, so material constraints will operate in the case of punctuation whether or not the author took an interest in this aspect of his text. We can also see that the semicolon is used much more frequently in the 1590 o than in the 1580 os. Of course, Nashe does not start writing until the end of that decade, but if we go back to Lyly's Euphues and His England, printed by Thomas East in 1580, which Nashe acknowledged as an early stylistic model, we find a distribution of 762 colons to 10 semicolons in a text of 92,973 words. From table 1 we can also see that in Nashe's earliest work of the 1590s, Pierce Penilesse, there is a significantly higher proportion of colons to semicolons than in work printed later in the decade. There is a great deal of reported speech in Pierce Penilesse, but this is not signaled by the colon, which is used consistently to partition sentences, as in the example given by Parkes. In the case of Have With You to Saffron-Walden, dialogue is embedded in the text in quasi-dramatic form, so in this work the colon is used quite frequently as a speech prefix rather than as punctuation within sentences. Although this feature of the text underlines its "oral" character, it narrows further the proportion of colons to semicolons as instruments for sentence partition. On this basis, the 159 os looks like the decade of transition from the colon to the semicolon.

The other main inference we can draw from the table is that when the semicolon does become available, its frequency is partly determined by textual genre (though that does not mean that the punctuation is a matter of authorial choice). The texts with the highest proportion of semicolons are discursive or argumentative works: the preface to Menaphon and Terrors of the Night. Interestingly, the text at the other end of the scale is not one of the more obviously rhetorical works but the picaresque narrative The Unfortunate Traveller, and the relationship between the rhetorical system of punctuation and early prose fiction might repay further investigation. All Nashe's writing is in varying degrees oral in the sense that it uses print to simulate

42. Thomas Nashe, The Anatomie of Absurditie (London, 1589), sig. C1r (this is part of a longer sentence); The Unfortunate Traveller and Other Works, ed. J. B. Steane (London, 1972), 472 . 


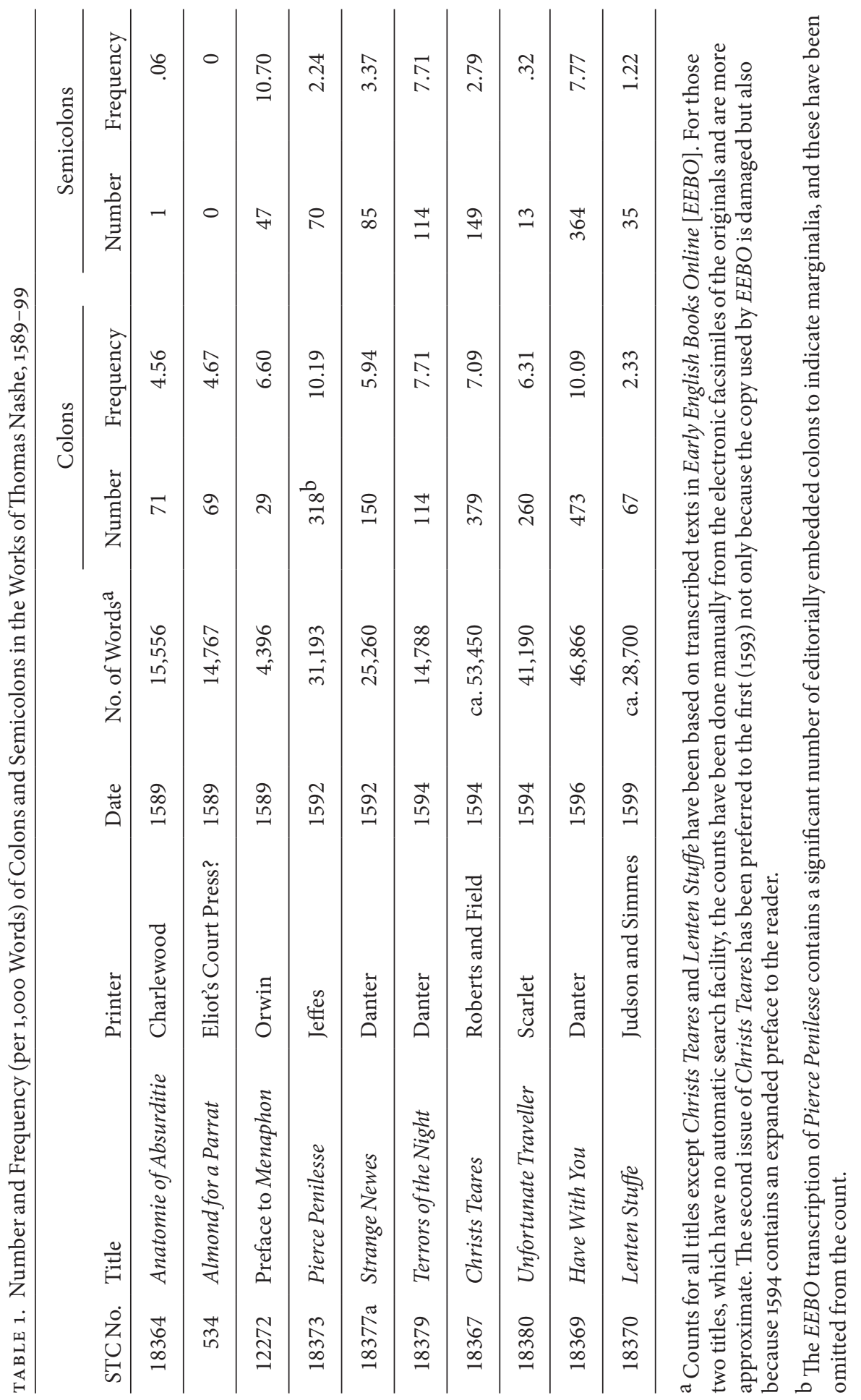


the mannerisms and conditions of speech. 43 Strange Newes and Have With You deploy this strategy in the context of polemic, but two other works-Christs Teares and Lenten Stuffe - take on what are perhaps the more distinctively rhetorical forms of lamentation and encomium. So I want finally to look more closely at some examples of colons and semicolons in these two texts. Can they reveal how the alternative systems of rhetorical notation and syntactical-semantic demarcation work together?

Christs Teares presents a relatively high proportion of semicolons to colons, and we can see different functions for the two signs emerging. The colon is quite frequently used in a way that makes sense rhetorically but not syntactically, as in this example: "Then on the suddaine starting backe, as ouer-examining the words he had sayd, and condemning himself (in his thought) for being so bitter: he presentlie weepeth," where modern punctuation would dispense with the comma after "sayd" and substitute a comma for the colon after "bitter." 44 By contrast, the semicolon often appears as a longer pause after a main clause and before a conjunction, as here:

In stead of girding and gathering vp thy loynes, thou vnloosest them to all licensiousnes; For the staffe of steadfastness, thou armest thy selfe with the broken Reed of inconstancie; And for incountering and contending with the flesh and the diuill, most slauishly thou kissest and imbracest them. (Fol. 11v)

This follows a sentence of five consecutive semicolons punctuating a series of parallel main clauses. Throughout Christs Teares, the semicolon is frequently followed by a capital, which suggests that it was seen as being closer to a period than a colon. 45 The semicolon also quite frequently has a recognizable syntactical rather than a rhetorical function, as here: "They would haue theyr mouthes reuerenced as the mouthes of the Sybils, who spoke nothing but was registred; Yet nothing comes from theyr mouthes, but grosse full-stomackt tautology" (fol. 63r). The colon, on the other hand, retains some of its rhetorical features in this work. It has a marked presence in the set-piece speech of the mother who eats her own child-a lamentation within a lamentation, which is marked by marginal quotation marks over several pages (fols. $33 \mathrm{r}-36 \mathrm{v}$ ). It also retains some of the qualities of the caesura from the psalms in sentences such as, "when thou killest me, kill her iniquities also: let thy deepe-entring Darte obliuionize

43. See Neil Rhodes, "On Speech, Print and New Media: Thomas Nashe and Marshall McLuhan," in "Sound Effects: The Oral/Aural Dimensions of Literature in English," ed. Chris Jones and Neil Rhodes, special issue, Oral Tradition 24, no. 2 (2009): 373-92, http://journal .oraltradition.org/issues/24ii/rhodes.

44. Thomas Nashe, Christs Teares ouer Ierusalem (London, 1594), fol. 4v. Subsequent citations of this edition are given in the text.

45. This runs contrary to the standard view, which positions the semicolon between the comma and the colon; see David Crystal, "Think on My Words": Exploring Shakespeare's Language (Cambridge, 2008), 68. 
their memories" or "The Sunne shyneth aswell on the good as the badde: God from on hie, beholdeth all the workers of iniquity" (fols. 23r, 24r). The rhetorical form of the lamentation naturally lends itself to psalm-like effects of this kind.

In Lenten Stuffe, there are examples of the colon being used in quasimodern fashion to signal reported speech, as in this passage:

The Popes caterer casting a licorous glaunce that way, asked what it was he had to sell: the king of fishes he answered: the king of fishes replied hee, what is the price of him? A hundred duckats he tolde him: a hundred duckats quoth the Popes caterer, that is a kingly price indeede, it is for no priuate man to deale with him: then hee is for mee sayd the Fisherman. 46

But what is really more striking about the punctuation of Nashe's final work is how relatively few incidences there are of either colon or semicolon. This is a breathless, comma-ridden text, largely uninterrupted by the mid-length pause. In fact, at one point even a paragraph ends with a comma. 47 This is presumably a printer's error, and yet it seems appropriate that the running from one paragraph into another should occur in this, the most rhetorically hectic of all Nashe's writings, and in the context of an observation about buildings too costly ever to be completed. The last word of the paragraph is "finished,"

The relative absence of the "media distinctio" is perhaps peculiar to Lenten Stuffe. But if the 159os, Nashe's decade, is also the decade of transition from the colon to the semicolon, it has to be said that this is a fairly muddled process. We can see elements of residual orality in the punctuation of Nashe's texts-passages that demonstrate the survival of the older system of punctuation as rhetorical notation-and we can also see the beginnings of a different, more logical system, which helps the reader to interpret the sentence. The colon and semicolon can sometimes reflect these two competing systems. But there are also instances where the two signs seem to be used interchangeably, as here, in another passage on building from the first issue of Christs Teares:

The phrase of Sermons, as it ought to agree with the scripture, so heede must be taken. That theyr whole Sermons, seeme not a banquet of broken fragments of scripture: that it be not usd but as the corner stone, to close vp any building; That they gather fruite, and not leaues: proofes and not phrases onely out of the Bible. (Fol. 65r)

46. Thomas Nashe, Lenten Stuffe (London, 1599), 54.

47. Nashe, Lenten Stuffe, 13. 
The fact that each of the longer pauses (period, colon, and semicolon) is used before the conjunctive "that" is testament to the radical indeterminacy of punctuation in these texts. We may note that there is, again, a capital after the semicolon but not after the colon and that there is a more modern use of the final colon, which expands or spells out what has gone before. But looking at how these two punctuation marks function in Nashe's prose texts (some of his writing is in verse) can only reinforce the sense that punctuation in this period is unstable and unsystematic. While we can find examples of arguably purposeful choices of colon or semicolon, these are probably outnumbered by examples of arbitrary uses of the two signs. This is what we would expect in a period of transition.

What this might mean for editors who are seeking to present these texts to the modern reader is uncertain. But it seems that the assertion by a recent Arden Shakespeare editor that standardizing punctuation "is both a sensible and uncontested policy" ought not, in fact, to be uncontested. $4^{8}$ While it might generally be agreed that adopting a regular set of conventions based upon syntactical structure helps to clarify the sense for the modern reader, such a system may erase the "oral" qualities of a writer such as Nashe. Here it is worth bearing in mind the view of one of the most acoustically sensitive of modern scholarly editors, Gavin Alexander, who argues that skillful modernization can actually enhance an understanding of "the rhythm, movement, and meaning of early modern syntax" and of "early modern rhetorical pointing." 49 This is, of course, a complex and contentious issue. The point here is to explore whether the presence of the colon indicates the survival of an older concept of punctuation, one of physiological origin and designed for aural effect-an essentially rhetorical system. In the examples we have seen from verse texts, from the psalms in both verse and prose, and from Cicero translated into English, all printed before the mid-158os, it is clear that it does. But in Nashe's prose writings of the 1590 s, its function is very much less clear: we can see the survival of the old system, the appearance of the new, and quite frequently the absence of any system at all. One thing that we can say with some certainty is that it is the advent of the semicolon that casts all in doubt, and that the appearance of this alternative to the colon initiates a long process of transition toward a different and more logical understanding of the function of punctuation. The world of the printed text shifted gradually, like the picture of the world itself.

I am most grateful to Peter Rhodes for his help with the data and to Gordon Kendal for his comments on periodicity.

48. Pamela Mason, "Editing the Text," appendix 1, pt. 1, in Macbeth, ed. Sandra Clark and Pamela Mason (London, 2015), 308.

49. Gavin Alexander, "The Problems with Old Spelling Editions," in A Handbook of Editing Early Modern Texts: A Handbook, ed. Clare Loffman and Harriet Phillips (Abingdon, U.K., 2018), 101 (2.3.2). Alexander does emphasize the depth and range of skills an editor needs in order to modernize successfully. 
NEIL RHODES is Professor of English Literature and Cultural History at the University of St. Andrews. He is Co-General Editor of the MHRA Tudor and Stuart Translations, and his most recent book is Common: The Development of Literary Culture in Sixteenth-Century England (2018). 
